\title{
VEGFA polymorphisms and cardiovascular anomalies in 22q11 microdeletion syndrome: a case-control and family-based study
}

\author{
JUAN FRANCISCO CALDERÓN ${ }^{1 *}$, ALONSO R. PUGA ${ }^{1}$, M. LUISA GUZMÁN, \\ CARMEN PAZ ASTETE ${ }^{2}$, MARTA ARRIAZA ${ }^{3}$, MARIANA ARACENA $^{2}$, \\ TERESA ARAVENA ${ }^{4}$, PATRICIA SANZ ${ }^{5}$ and GABRIELA M. REPETTO ${ }^{1}$ \\ ${ }^{1}$ Center for Human Genetics, Facultad de Medicina, Clínica Alemana-Universidad del Desarrollo \\ ${ }^{2}$ Hospital Dr. Luis Calvo Mackenna \\ ${ }^{3}$ Hospital Dr. Gustavo Fricke \\ ${ }^{4}$ Complejo Hospitalario Dr. Sótero del Río \\ ${ }^{5}$ Hospital Clínico Universidad de Chile
}

\begin{abstract}
Microdeletion 22q11 in humans causes velocardiofacial and DiGeorge syndromes. Most patients share a common $3 \mathrm{Mb}$ deletion, but the clinical manifestations are very heterogeneous. Congenital heart disease is present in $50-80 \%$ of patients and is a significant cause of morbidity and mortality. The phenotypic variability suggests the presence of modifiers. Polymorphisms in the VEGFA gene, coding for the vascular endothelial growth factor A, have been associated with non-syndromic congenital heart disease, as well as with the presence of cardiovascular anomalies in patients with microdeletion 22q11. We evaluated the association of VEGFA polymorphisms c.-2578C >A (rs699947), c.-1154G >A (rs1570360) and c.-634C>G (rs2010963) with congenital heart disease in Chilean patients with microdeletion 22q11. The study was performed using casecontrol and family-based association designs. We evaluated 122 patients with microdeletion $22 \mathrm{q} 11$ and known anatomy of the heart and great vessels, and their parents. Half the patients had congenital heart disease. We obtained no evidence of association by either method of analysis. Our results provide further evidence of the incomplete penetrance of the cardiovascular phenotype of microdeletion 22q11, but do not support association between VEGFA promoter polymorphisms and the presence of congenital heart disease in Chilean patients with this syndrome.
\end{abstract}

Key terms: congenital heart disease, DiGeorge syndrome, genetic modifiers, VEGFA, velocardiofacial syndrome

\section{INTRODUCTION}

Microdeletion 22q11 syndrome (del22q11) is the most frequent known microdeletion syndrome in humans with an estimated incidence of 1/4,000-1/10,000 live births (reviewed in Kobrynski and Sullivan 2007). The microdeletion causes of approximately $80-90 \%$ of cases of DiGeorge syndrome and $95-100 \%$ of cases of velocardiofacial (VCFS) and conotruncal anomaly face syndromes. The clinical manifestations of del22q11 are highly variable, and over 180 clinical features have been described. The most frequent findings include congenital heart disease (CHD), seen in 50-80\% of patients, palatal abnormalities in $70-100 \%$, endocrine defects such as hypoparathyoidism, hypothyroidism and growth hormone deficiency in $15-50 \%$, immune deficiencies in $10 \%$, learning disabilities in 50-80\% and psychiatric

Address correspondence to: Gabriela M. Repetto, MD, Center for Human Genetics, Facultad de Medicina, Clínica Alemana-Universidad del Desarrollo, Av. Las Condes 12438, Santiago, Chile 771 0162, Email: grepetto@udd.cl, Ph 562 327 9517, FAX 5623279507

* currently at McKusick-Nathans Institute of Genetic Medicine, Johns Hopkins University School of Medicine, Baltimore, MD, USA 
disorders in 6-30\% of affected individuals (Kobrynski and Sullivan 2007; McDonaldMcGinn et al., 1999; Ryan et al., 1997; Vantrappen et al., 1999, Repetto et al., 2009). The majority of patients share a common $3 \mathrm{Mb}$ deletion, encompassing more than 30 genes. Despite this molecular similarity among patients, the clinical manifestations can vary widely. Presentation of patients with the same deletion can range from a severely ill newborn with DiGeorge syndrome, having congenital heart disease, thymic hypoplasia, hypoparathyoidism and a cleft palate, to a school age child with learning disabilities, diagnosed on the basis of characteristic facial features and hypernasal speech due to velopharyngeal insufficiency.

A major role for haploinsufficiency of the TBX1 gene in the etiology of the congenital anomalies of the syndrome has been proposed. TBX1 is located within the common deletion region and encodes for a transcription factor, T-box 1 , which has a relevant role in the formation of the pharyngeal arches and pouches, precursors of the cardiac outflow tract and the craniofacial and cervical structures affected in the syndrome. TBX1-haploinsufficient mice show a reduction in thickness or an absence of the $4^{\text {th }}$ branchial arteries in 20$40 \%$ of embryos. Homozygous mutant mice all have cardiac and aortic abnormalities, as well as craniofacial and cervical anomalies. A bacterial artificial chromosome (BAC) containing TBX1 rescues the cardiovascular anomalies in mice hemizygous for the deletion. Varying frequencies of heart defects are seen in mice with hypomorphic or null TBX1 alleles (Jerome and Papaioannou 2001; Liao et al., 2004; Lindsay et al., 2001; Merscher et al., 2001). In addition, a small number of non-deleted patients with VCFS phenotype have been found to harbor mutations in TBX1 (Yagi et al., 2003).

The studies in animal models have also shown that the phenotype of TBX1 haploinsufficient mice varies depending on the strain. Specifically, the penetrance of the cardiovascular anomalies is different in inbred mice compared to mixed genetic background ones, although the types of anomalies are comparable (Jerome and Papaioannou 2001; Taddei et al., 2001). These observations suggest a role for genetic modifiers of the primary effect of the deletion, which may account for the phenotypic variability. In mouse models, candidate genes include Fgf8, encoding for fibroblast growth factor 8 (Vitelli et al., 2002), VEGFA, encoding for vascular endothelial growth factor A (Stalmans et al., 2003), Pitx2, encoding for the pairedlike homeodomain transcription factor 2 (Nowotschin et al., 2006) and Crkl, encoding for $\mathrm{V}-\mathrm{CRK}$ avian sarcoma virus CT10 oncogene homologue-like (Moon et al., 2006).

The role of these and other factors as potential modifiers of the phenotype in humans with del22q11 has not been clearly delineated. VEGFA, located in human chromosome region $6 \mathrm{p} 12$, encodes for the vascular endothelial growth factor A that has a crucial role in angiogenesis. In addition to this function, animal models bearing hypomorphic variants of VEGFA and association studies in patients with nonsyndromic CHD have implicated it in structural cardiac anomalies, suggesting a role for VEGFA in heart formation (Lambrechts and Carmeliet 2004; Lambrechts et al., 2005; Stalmans et al., 2003; Vannay et al., 2006; Xie et al., 2007). Stalmans et al. (2003) studied VEGFA polymorphisms c.-2578C >A (rs699947), c.$1154 \mathrm{G}>\mathrm{A}(\mathrm{rs} 1570360)$ in the promoter region and c. $-634 \mathrm{C}>\mathrm{G}(\mathrm{rs} 2010963)$ in the 5 , untranslated region (5'UTR) and the presence of congenital heart disease (CHD) in a case-control study of Flemish patients with del22q11 and provided evidence of association with the latter 2 SNPs (Stalmans et al., 2003). These polymorphisms are known to downregulate VEGFA expression (Awata et al., 2002; Lambrechts et al., 2005; Shahbazi et al., 2002). Given the relevance of validation of these studies in independent populations, and the benefits of using test for association that reduce potential population stratification bias (Ott 2004; Lewis 2002), we evaluated the association of these 3 polymorphisms in the VEGFA promoter with the presence of CHD in Chilean 
patients with del22q11, using case-control and family-based designs.

\section{METHODS}

Patients with del22q11 syndrome, confirmed by fluorescence in situ hybridization (FISH) testing with TUPLE1 probe (Abbott Molecular, IL, USA), and known cardiac and great vessel anatomy by cardiac ultrasound, angio-computed tomography or catheterization, were invited to participate. The study was approved by the Ethics Committee at each participating institution, and all participants and/or their parents gave written informed consent.

Patients had been diagnosed with del22q11 and were followed in 5 centers in Santiago and one in Viña del Mar, Chile. Clinical information was collected by a standard questionnaire, and peripheral blood samples for DNA extraction were obtained from each patient and his/her parents. The patients are part of the cohort described by Repetto et al (2009). Patients were classified as with or without congenital heart based on their imaging studies. Patients with normal intracardiac anatomy, but with abnormalities of the great vessels such as right sided aortic arch or aberrant subclavian artery, were classified as having CHD. Only the primary or most significant defect was considered for the analysis. For the purpose of this study, patients with intracardiac or great vessel anomaly were considered cases, and those with normal anatomy, were considered controls. Data was collected and statistical analysis performed using SPSS v12.0 (SPSS Inc, Chicago, IL, USA). Comparisons of clinical and demographic features between cases and controls were performed by $\mathrm{X}^{2}$ or Fisher's exact test for categorical variables, and Student's t test for quantitative variables.

VEGFA polymorphisms c.-2578C >A (rs699947), c.-1154G $>$ A (rs1570360), c.$634 \mathrm{C}>\mathrm{G}$ (rs2010963) were analyzed by polymerase chain reaction followed by restriction enzyme assay as previously described (Xie et al., 2007) and confirmed by capillary sequencing. Allelic and genotypic frequencies of these 3 polymorphisms were compared between patients with del22q11 with CHD (cases) and without CHD (controls) by $\mathrm{X}^{2}$ testing. Transmission disequilibrium testing (TDT) was performed to evaluate the transmission of alleles from parents to offspring with and without CHD. This method eliminates population stratification bias and does not require genotypes of additional unaffected relatives. Analysis in families of individuals with and without CHD was performed using the family-based association test (FBAT) method (Horvath et al., 2001) (available at http: // www.biostat.harvard.edu/ fbat/fbat.htm)

Haplotypes for the 3 polymorphisms in VEGFA were constructed from the patients' and parents' genotypes using Haploview (Barrett et al., 2005) (available at http: // www.broad.mit.edu/haploview/haploviewdownloads). The haplotype frequencies were compared between patients with and without CHD by $\mathrm{X}^{2}$ test. A p-value of 0.05 or less was considered evidence of statistically significant difference.

\section{RESULTS}

One hundred and twenty two patients with $22 q 11$ del were included in the study. The mean age $( \pm 1$ SD) at diagnosis of the syndrome was $6.3 \pm 8.1$ years, ranging from newborn to 37.9 years of age. Sixty one cases $(50.0 \%)$ had CHD. Forty-four percent were male and no gender difference was observed between patients with and without CHD. Patients with CHD were diagnosed at a significantly earlier age than those without CHD. A higher frequency of palatal abnormalities was observed in patients without CHD. Eight cases $(6.6 \%)$ were inherited, all of them from an affected mother. Only one of the affected mothers had CHD. Relevant clinical features of the patients and types and relative frequencies of CHD are summarized in Tables I and II, respectively.

Samples from 110 mothers and 100 fathers were obtained, resulting in 99 complete trios for TDT analysis, $49 \%$ of them from patients with CHD. Allelic and 
TABLE I

Clinical characterization of patients with del22q11

\begin{tabular}{|c|c|c|c|}
\hline & $\begin{array}{c}\text { With CHD } \\
(\mathrm{n}=61)\end{array}$ & $\begin{array}{c}\text { Without CHD } \\
(\mathrm{n}=61)\end{array}$ & $\mathrm{p}$ value \\
\hline n Males/Females & $28 / 33$ & $26 / 35$ & $0.85^{*}$ \\
\hline Age at diagnosis in years (mean \pm 1 standard deviation) & $3.9 \pm 5.3$ & $8.6 \pm 9.4$ & $0.001 * *$ \\
\hline Median age at diagnosis in years & 1.1 & 6.6 & \\
\hline $\begin{array}{l}\text { Palatal abnormalities, } \mathrm{n} \text { affected patients/ } \mathrm{n} \text { with available } \\
\text { data }(\%)\end{array}$ & $31 / 50(62.0)$ & $48 / 56(86.0)$ & $0.005 * *$ \\
\hline Deceased, $\mathrm{n}$ patients & 2 & 0 & $0.49 * * *$ \\
\hline
\end{tabular}

* $\mathrm{X}^{2}$ test ${ }^{* *}$ Student's $\mathrm{t}$ test ${ }^{* * *}$ Fisher's exact test

TABLE II

Results of cardiovascular evaluation

\begin{tabular}{lcc}
\hline Diagnosis & N patients & $\%$ \\
\hline Normal & 61 & 50 \\
Tetralogy of Fallot & 24 & 19.7 \\
Ventricular septal defect & 13 & 10.7 \\
Interrupted aortic arch type b & 7 & 5.7 \\
Coarctation of the aorta & 4 & 3.3 \\
Atrial septal defect & 4 & 3.3 \\
Truncus arteriosus & 3 & 2.5 \\
Other anomalies & 6 & 4.8 \\
\hline
\end{tabular}

genotypic frequencies of VEGFA promoter polymorphisms in the parents were in Hardy-Weinberg equilibrium. Minor allele frequencies were 0.47 for $-2578 \mathrm{~A}, 0.27$ for $-1154 \mathrm{~A}$, and 0.37 for $-634 \mathrm{C}$. These figures are similar to the healthy control population described by Stalmans et al. (2003), of $0.44,0.31$ and 0.32 , respectively.

Allelic and genotypic frequencies in patients with del22q11 are summarized in Table III. We observed no statistically significant differences in frequencies between patients with and without CHD.

Linkage disequilibrium (LD) metrics were $D^{\prime}=0.822$ and $r^{2}=0.289$ between SNPs -2578 and $-1154, D^{\prime}=0.857$ and $r^{2}$
$=0.176$ between -1154 and -634 , and $\mathrm{D}^{\prime}=0.644$ and $\mathrm{r}^{2}=0.233$ between -2578 and -634. VEGFA promoter haplotype frequencies showed no statistically significant difference in patients with or without CHD (Table IV). TDT results are summarized in Table V. We observed no evidence of statistically significant overtransmission of any of the lower activity VEGFA SNPs to patients either with or without CHD.

\section{DISCUSSION}

CHD is a frequent manifestation of del22q11, often requiring complex surgical and intensive care management (Jatana et al., 2007). In addition, a higher immediate postoperative mortality has been seen for CHD repair in children with del22q11, compared to children with other syndromes and non-syndromic CHD (Anaclerio et al., 2004). Kyburz et al.(2008) described a 1year survival of $85 \%$ and a 5-year survival of $80 \%$ in del22q11 patients with CHD. Given the relatively high frequency of the deletion, the consequences of CHD in morbidity and mortality, the increased survival of the patients and its autosomal dominant transmission, it is relevant to identify the factors that contribute to the risk of having CHD in this group of individuals. 
TABLE III

Allelic and genotypic frequencies of VEGFA promoter polymorphisms in patients with del22q11, with and without CHD

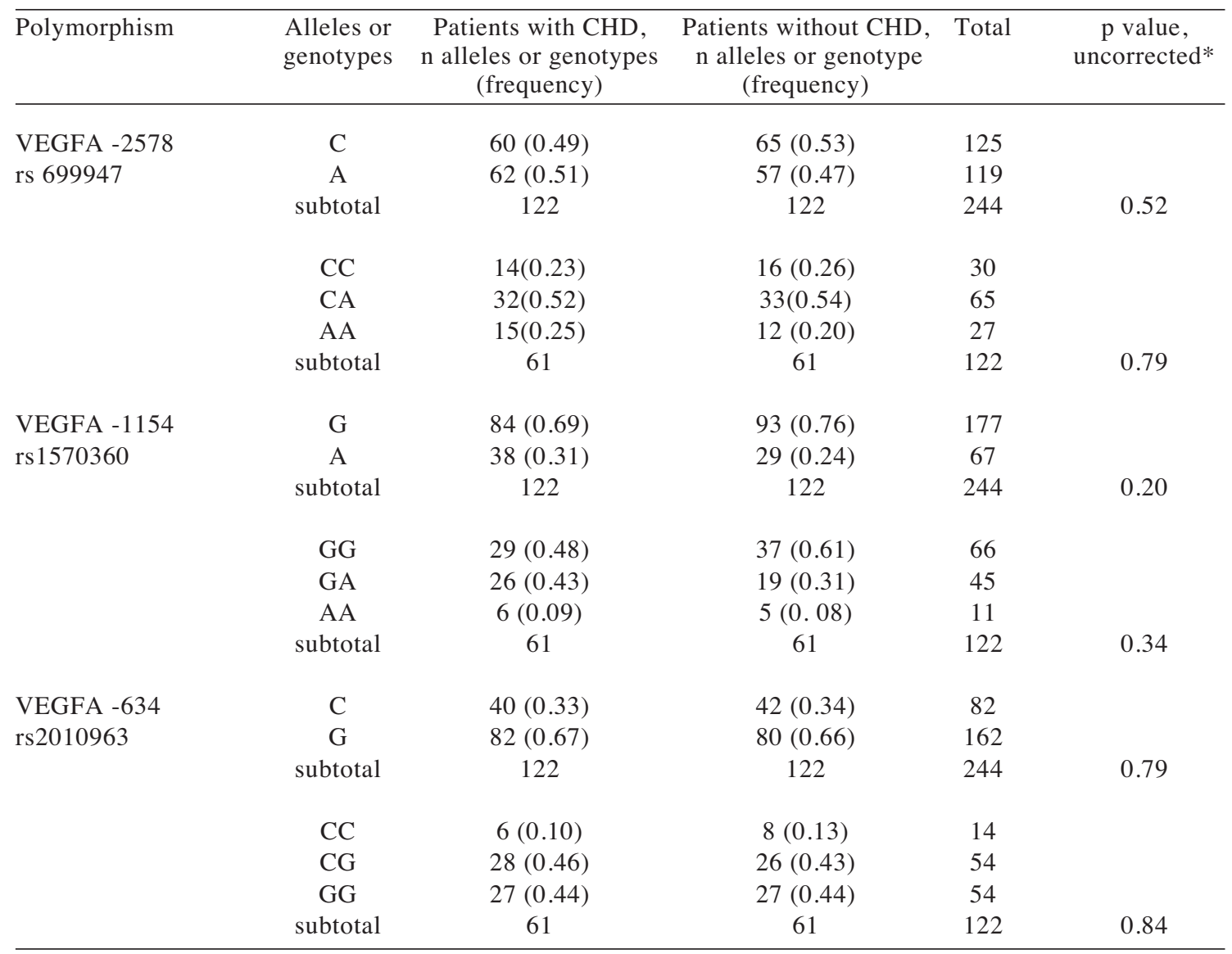

$* \mathrm{X}^{2}$ test

TABLE IV

VEGFA promoter haplotype analysis. Haplotypes are expressed with alleles in the following order: c.-2578C $>$ A (rs699947), c.-1154G $>$ A (rs1570360), c.-634C $>$ G (rs2010963)

\begin{tabular}{|c|c|c|c|c|c|}
\hline \multirow[b]{2}{*}{ Haplotype } & \multicolumn{2}{|c|}{ Patients with CHD } & \multicolumn{2}{|c|}{ Patients without CHD } & \multirow[t]{2}{*}{ p value* } \\
\hline & $\mathrm{n}$ & frequency & $\mathrm{n}$ & frequency & \\
\hline CGC & 18 & 0.3 & 18 & 0.3 & 1 \\
\hline AAG & 18 & 0.3 & 13 & 0.22 & 0.69 \\
\hline CGG & 11 & 0.17 & 15 & 0.24 & 0.50 \\
\hline AGG & 11 & 0.17 & 11 & 0.18 & 1 \\
\hline AGC & 2 & 0.04 & 4 & 0.06 & 0.68 \\
\hline CAG & 1 & 0.02 & 0 & 0 & 1 \\
\hline
\end{tabular}

$* \mathrm{X}^{2}$ test 
TABLE V

Transmission disequilibrium testing of VEGFA hypomorphic promoter polymorphisms in families of patients with del22q11, with or without CHD

\begin{tabular}{lcccccc}
\hline SNP & $\begin{array}{c}\text { Clinical } \\
\text { diagnosis }\end{array}$ & $\begin{array}{c}\mathrm{n} \text { informative } \\
\text { parents }\end{array}$ & $\begin{array}{c}\mathrm{n} \text { transmitted } \\
\text { alleles }\end{array}$ & $\begin{array}{c}\mathrm{n} \text { non-transmitted } \\
\text { alleles }\end{array}$ & T value* & p value \\
\hline \multirow{2}{*}{$-2578 \mathrm{~A}(\mathrm{rs} 699947)$} & With & 49 & 27 & 22 & 0.33 & 0.57 \\
& Without CHD & 50 & 28 & 22 & 0.5 & 0.47 \\
$-1154 \mathrm{~A}(\mathrm{rs} 1570360)$ & With CHD & 43 & 28 & 15 & 3.35 & 0.06 \\
& Without CHD & 35 & 14 & 21 & 1.03 & 0.32 \\
$-634 \mathrm{G}(\mathrm{rs} 2010963)$ & With CHD & 36 & 15 & 21 & 0.69 & 0.41 \\
& Without CHD & 41 & 26 & 15 & 2.44 & 0.11 \\
\hline
\end{tabular}

* McNemar test

This series shows a lower frequency of CHD compared to other large series of reported patients (McDonald-McGinn et al., 1999; Ryan et al., 1997). This may be due to regional or ethnic differences in phenotype or to increased awareness of this syndrome in patients presenting palatal anomalies or cognitive deficits. As described by Oskarsdottir et al., (2005), diagnosis of del22q11 was made significantly later in patients without CHD, since facial and other features may be subtle and not obviously recognized in the neonatal or early infancy periods.

This study evaluated VEGFA promoter polymorphisms and the presence or absence of CHD in a large number of Chilean patients with 22q11 deletion, and found no evidence of association, analyzing the results by case-control design or by TDT, a more robust association test used to avoid population stratification bias. The results contrast with the findings published by Stalmans et al. (2003) in a Flemish group of del22q11 patients that showed a higher frequency of VEGFA promoter SNPs 2578A and $-1154 \mathrm{~A}$ in patients with CHD. As has been described for many other allelic association studies (Ott 2004), these findings were not replicated in our study. This may be due to ethnic differences among the 2 populations, leading perhaps to association with different VEGFA polymorphisms in each of them, or to lack of association, at least in Chilean patients. Alternatively, the sample size may have been insufficient to detect smaller effects, though the study by Stalmans et al. (2003) included a smaller sample size (58 patients with CHD and 33 without) than the present study. Moreover, a recent study of TDT in over 700 cases of non-syndromic CHD and meta-analysis of VEGFA polymorphism in another 500 cases showed no evidence of association, questioning the role of this gene in non-syndromic CHD susceptibility (Griffin et al., 2009).

Similar apparently contradictory findings for another important phenotypic feature of del22q11, psychiatric disease, and COMT gene polymorphism have been published. COMT encodes for cathecol-Omethyltransferase and is located within the deletion region and is therefore haploinsufficient in del22q11. Studies have reported association between COMT 158 Met, a low activity allele and bipolar spectrum disorder (Lachman et al., 1996) or clinically significant behavior problems (Bearden et al., 2005) in patients with del22q11 but others (Baker et al., 2005; Murphy et al., 1999) have found no association with psychotic symptoms or schizophrenia. These differences may be due to factors related to study design that limits their comparison, or to spurious association.

The factors involved in the incomplete penetrance of the cardiovascular abnormalities in patients with del22q11 remain unknown. Additional studies of recently identified downstream targets of 
TBX1 (Liao et al., 2008), genes relevant in the embryonic development of the structures affected in del22q11, or analysis of other genes identified by genome-wide association studies, will be relevant to improve our understanding of the pathogenesis and variability of this common genetic syndrome.

\section{ACKNOWLEDGEMENTS}

The authors wish to thank the patients and parents who participated in the study, Dimitrios Avramopoulos, MD PhD, for helpful statistical advice and Bruce Korf, MD PhD, for review of the manuscript. This project was funded by Fondecyt-Chile, grant 1061051.

\section{REFERENCES}

ANACLERIO S, DI CIOMMO V, MICHIELON G, DIGILIO MC, FORMIGARI R, PICCHIO FM, GARGIULO G, DI DONATO R, DE IORIS MA, MARINO B (2004). Conotruncal heart defects: impact of genetic syndromes on immediate operative mortality. Ital Heart J 5: 624-628

AWATA T, INOUE K, KURIHARA S, OHKUBO T, WATANABE M, INUKAI K, INOUE I, KATAYAMA $S$ (2002). A common polymorphism in the 5'untranslated region of the VEGFA gene is associated with diabetic retinopathy in type 2 diabetes. Diabetes 51: 1635-1639

BAKER K, BALDEWEG T, SIVAGNANASUNDARAM S, SCAMBLER P, SKUSE D (2005). COMT Val108/ 158 Met modifies mismatch negativity and cognitive function in 22q11 deletion syndrome. Biol Psychiatry 58: $23-31$

BARRETT JC, FRY B, MALLER J, DALY MJ (2005). Haploview: analysis and visualization of LD and haplotype maps. Bioinformatics 21: 263-265

BEARDEN CE, JAWAD AF, LYNCH DR, MONTEROSSSO JR, SOKOL S, MCDONALDMCGINN DM, SAITTA SC, HARRIS SE, MOSS E, WANG PP, ZACKAI E, EMANUEL BS, SIMON TJ (2005). Effects of COMT genotype on behavioral symptomatology in the 22q11.2 Deletion Syndrome. Child Neuropsychol 11: 109-117

GRIFFIN HR, HALL DH, TOPF A, EDEN J, STUART AG, PARSONS J, PEART I, DEANFIELD JE, O'SULLIVAN J, BABU-NARAYAN SV, GATZOULIS MA, BU'LOCK FA, BHATTACHARYA $S$, BENTHAM J, FARRALL M, RIVERON JG, BROOK JD, BURN J, CORDELL HJ, GOODSHIP JA, KEAVNEY B (2009). Genetic variation in VEGF does not contribute significantly to the risk of congenital cardiovascular malformation. PLoS ONE 4(3): e4978. doi: 10.1371/journal.pone.0004978

HORVATH S, XU X, LAIRD NM (2001). The family based association test method: strategies for studying general genotype-phenotype associations. Eur J Hum Genet 9: 301-306

JATANA V, GILLIS J, WEBSTER BH, ADES LC (2007). Deletion 22q11.2 syndrome-implications for the intensive care physician. Pediatr Crit Care Med 8: 459463

JEROME LA, PAPAIOANNOU VE (2001). DiGeorge syndrome phenotype in mice mutant for the T-box gene, Tbx1. Nat Genet 27: 286-291

KOBRYNSKI LJ, SULLIVAN KE (2007). Velocardiofacial syndrome, DiGeorge syndrome: the chromosome 22q11.2 deletion syndromes. Lancet 370: 1443-1452

KYBURZ A, BAUERSFELD U, SCHINZEL A, RIEGEL $M$, HUG $M$, TOMASKE $M$, VALSANGIACOMO BUCHEL ER (2008). The fate of children with microdeletion 22q11.2 syndrome and congenital heart defect: clinical course and cardiac outcome. Pediatr Cardiol 29: 76-83

LACHMAN HM, MORROW B, SHPRINTZEN R, VEIT S, PARSIA SS, FAEDDA G, GOLDBERG R, KUCHERLAPATI R, PAPOLOS DF (1996). Association of codon 108/158 catechol-Omethyltransferase gene polymorphism with the psychiatric manifestations of velo-cardio-facial syndrome. Am J Med Genet 67: 468-472

LAMBRECHTS D, CARMELIET P (2004). Genetics in zebrafish, mice, and humans to dissect congenital heart disease: insights in the role of VEGF. Curr Top Dev Biol 62: 189-224

LAMBRECHTS D, DEVRIENDT K, DRISCOLL DA, GOLDMUNTZ E, GEWILLIG M, VLIETINCK R, COLLEN D, CARMELIET P (2005). Low expression VEGF haplotype increases the risk for tetralogy of Fallot: a family based association study. J Med Genet 42: $519-522$

LEWIS CM (2002). Genetic association studies: design, analysis and interpretation. Brief Bioinform 3: 146-153

LIAO J, AGGARWAL VS, NOWOTSCHIN S, BONDAREV A, LIPNER S, MORROW BE (2008). Identification of downstream genetic pathways of Tbx 1 in the second heart field. Dev Biol 316: 524-537

LIAO J, KOCHILAS L, NOWOTSCHIN S, ARNOLD JS, AGGARWAL VS, EPSTEIN JA, BROWN MC, ADAMS J, MORROW BE (2004). Full spectrum of malformations in velo-cardio-facial syndrome/ DiGeorge syndrome mouse models by altering Tbx 1 dosage. Hum Mol Genet 13: 1577-1585

LINDSAY EA, VITELLI F, SU H, MORISHIMA M, HUYNH T, PRAMPARO T, JURECIC V, OGUNRINU G, SUTHERLAND HF, SCAMBLER PJ, BRADLEY A, BALDINI A (2001). Tbx1 haploinsufficieny in the DiGeorge syndrome region causes aortic arch defects in mice. Nature 410: 97-101.

MCDONALD-MCGINN DM, KIRSCHNER R, GOLDMUNTZ E, SULLIVAN K, EICHER P, GERDES M, MOSS E, SOLOT C, WANG P, JACOBS I, HANDLER S, KNIGHTLY C, HEHER K, WILSON M, MING JE, GRACE K, DRISCOLL D, PASQUARIELLO P, RANDALL P, LAROSSA D, EMANUEL BS, ZACKAI EH (1999). The Philadelphia story: the 22q11.2 deletion: report on 250 patients. Genet Couns 10: 11-24

MERSCHER S, FUNKE B, EPSTEIN JA, HEYER J, PUECH A, LU MM, XAVIER RJ, DEMAY MB, RUSSELL RG, FACTOR S, TOKOOYA K, JORE BS, LOPEZ M, PANDITA RK, LIA M, CARRION D, XU H, SCHORLE H, KOBLER JB, SCAMBLER P, WYNSHAW-BORIS A, SKOULTCHI AI, MORROW BE, KUCHERLAPATI R (2001). TBX1 is responsible 
for cardiovascular defects in velo-cardio-facial/ DiGeorge syndrome. Cell 104: 619-629

MOON AM, GURIS DL, SEO JH, LI L, HAMMOND J, TALBOT A, IMAMOTO A (2006). Crkl deficiency disrupts Fgf8 signaling in a mouse model of 22q11 deletion syndromes. Dev Cell 10: 71-80

MURPHY KC, JONES LA, OWEN MJ (1999). High rates of schizophrenia in adults with velo-cardio-facial syndrome. Arch Gen Psychiatry 56: 940-945

NOWOTSCHIN S, LIAO J, GAGE PJ, EPSTEIN JA, CAMPIONE M, MORROW BE (2006). Tbx1 affects asymmetric cardiac morphogenesis by regulating Pitx2 in the secondary heart field. Development 133: 15651573

OSKARSDOTTIR S, PERSSON C, ERIKSSON BO, FASTH A (2005). Presenting phenotype in 100 children with the $22 \mathrm{q} 11$ deletion syndrome. Eur J Pediatr 164: 146-153

OTT J (2004). Association of genetic loci: Replication or not, that is the question. Neurology 63: 955-958

REPETTO GM, GUZMÁN ML, PUGA A, CALDERÓN JF, ASTETE CP, ARACENA M, ARRIAZA M, ARAVENA T, SANZ P. (2009) Clinical features of Chromosome 22q11.2 microdeletion syndrome in 208 Chilean Patients (2009). Clin Genet 76: 465-470

RYAN AK, GOODSHIP JA, WILSON DI, PHILIP N, LEVY A, SEIDEL $H$, SCHUFFENHAUER $S$, OECHSLER H, BELOHRADSKY B, PRIEUR M, AURIAS A, RAYMOND FL, CLAYTON-SMITH J, HATCHWELL E, MCKEOWN C, BEEMER FA, DALLAPICCOLA B, NOVELLI G, HURST JA, IGNATIUS J, GREEN AJ, WINTER RM, BRUETON L, BRONDUM-NIELSEN K, SCAMBLER PJ (1997). Spectrum of clinical features associated with interstitial chromosome 22q11 deletions: a European collaborative study. J Med Genet 34: 798-804

SHAHBAZI M, FRYER AA, PRAVICA V, BROGAN IJ, RAMSAY HM, HUTCHINSON IV, HARDEN PN (2002). Vascular endothelial growth factor gene polymorphisms are associated with acute renal allograft rejection. J Am Soc Nephrol 13: 260-264

STALMANS I, LAMBRECHTS D, DE SMET F, JANSEN S, WANG J, MAITY S, KNEER P, VON DER OHE M,
SWILLEN A, MAES C, GEWILLIG M, MOLIN DG, HELLINGS P, BOETEL T, HAARDT $M$, COMPERNOLLE V, DEWERCHIN M, PLAISANCE $S$, VLIETINCK R, EMANUEL B, GITTENBERGERDE GROOT AC, SCAMBLER P, MORROW B, DRISCOL DA, MOONS L, ESGUERRA CV, CARMELIET G, BEHN-KRAPPA A, DEVRIENDT K, COLLEN D, CONWAY SJ, CARMELIET P (2003). VEGF: a modifier of the del22q11 (DiGeorge) syndrome? Nat Med 9: 173-182

TADDEI I, MORISHIMA M, HUYNH T, LINDSAY EA (2001). Genetic factors are major determinants of phenotypic variability in a mouse model of the DiGeorge/del22q11 syndromes. Proc Natl Acad Sci U S A 98: 11428-11431

VANNAY A, VASARHELYI B, KORNYEI M, TRESZL A, KOZMA G, GYORFFY B, TULASSAY T, SULYOK E (2006). Single-nucleotide polymorphisms of VEGF gene are associated with risk of congenital valvuloseptal heart defects. Am Heart J 151: 878-881

VANTRAPPEN G, DEVRIENDT K, SWILLEN A, ROMMEL N, VOGELS A, EYSKENS B, GEWILLIG M, FEENSTRA L, FRYNS JP (1999). Presenting symptoms and clinical features in 130 patients with the velo-cardio-facial syndrome. The Leuven experience. Genet Couns 10: 3-9

VITELLI F, TADDEI I, MORISHIMA M, MEYERS EN, LINDSAY EA, BALDINI A (2002). A genetic link between $\mathrm{Tbx} 1$ and fibroblast growth factor signaling. Development 129: 4605-4611

XIE J, YI L, XU ZF, MO XM, HU YL, WANG DJ, REN HZ, HAN B, WANG Y, YANG C, ZHAO YL, SHI DQ, JIANG YZ, SHEN L, QIAO D, CHEN SL, YU BJ (2007). VEGF C-634G polymorphism is associated with protection from isolated ventricular septal defect: case-control and TDT studies. Eur J Hum Genet 15: 1246-1251

YAGI H, FURUTANI Y, HAMADA H, SASAKI T, ASAKAWA S, MINOSHIMA S, ICHIDA F, JOO K, KIMURA M, IMAMURA S, KAMATANI N, MOMMA K, TAKAO A, NAKAZAWA M, SHIMIZU N, MATSUOKA R (2003). Role of TBX1 in human del22q11.2 syndrome. Lancet 362: 1366-1373. 